\title{
Introduction:
}

\section{Arctic International Relations in a Widened Security Perspective}

\author{
Marc Jacobsen, PhD Candidate, Centre for Advanced Security Theory, Department of \\ Political Science, University of Copenhagen
}

Victoria Herrmann, PhD Candidate, Scott Polar Research Institute, University of Cambridge

"If there is a Third World War, it's strategic center will be the north pole." - US General Harp Arnold (1946)

Since the militarization of the circumpolar north during the Cold War, the Arctic has been imagined and analyzed as a space of (in)security. The relic stations of the Distant Early Warning System and the still active Russian and American polar nuclear submarine fleets hold testament to the $20^{\text {th }}$ Century construction of not only a physical polar security space, but rhetorical spaces that came to construct an imagined North that informed southern publics and politicians whom would never travel above 66 degrees North. Today, one of the dominant narratives of and valuation metrics for the Arctic in public discourse is still one of security. It has been over two decades since the Cold War thawed into amiable relations between the Western powers and the Soviet Union. And yet, as the ice at the top of the world melts, there has been a stark increase in the focus of scholarship, journalism, and discourse on a race for resources and remilitarization in what has been termed the "new cold war". With this increasing securitization, the rhetoric that once divided the globe has been revived through narrow views of an Arctic security framework (Herrmann 2015). There are reports on how to avoid a new Cold War complete with photographs of tanks (Cohen et al. 2008); news articles on Russia preparing for an 'ice-cold war' (Scarborough, 2017); and interviews that suggest America is falling behind on the new Cold War over Arctic oil (Johnson and De Lucem 2016). As neither most politicians nor the citizens they represent will travel to the northernmost region, the warnings of chilled relations in the $21^{\text {st }}$ Century that loom in text and titles of scholarship and print media are integral in shaping perceptions of not only circumpolar security, but also opportunities to cooperate in mitigating those security threats. 
There are many scholars of International Relations that focus on security studies beyond the militarization of the North Pole, particularly those of energy security, as vanishing sea ice makes offshore petroleum exploration feasible, and on the security of all humanity, as a warming Arctic raises sea levels and produces more volatile weather patterns for the rest of the globe. However, such scholarship fails to engage the complexity and multidimensional aspects of Arctic security that might foster a deeper understanding of the region, and in turn more nuanced cooperation and exchange of expertise between security actors. Much of the current Arctic security discourse focuses analyses on singular, linear dimensions - most notably military and energy. In such a rapidly changing Arctic, there is a need to engage in a comprehensive investigation into what Arctic security means in the $21^{\text {st }}$ Century. Climate change, globalization, urbanization, and demographic shifts are transforming the cultures, landscapes, economies, and socio-political structures of the circumpolar region. This special issue of Politik aims to widen the debate on Arctic security relations through a more comprehensive dialogue inclusive of the many different types of security, their interactions, and their challenges by using the theoretical approach of the Copenhagen School. A better understanding of security dynamics in the circumpolar North today demands a critical analysis of those changes through a multidisciplinary and multi-modal lens. Each chapter in this special issue provides one layer of that multimodal lens of Arctic security that, together, weave a complex web of change. This special issue therefore continues to move the discourse of polar security beyond - but not excluding - the conventional debates of military capabilities and state sovereignty towards a more comprehensive definition of security, including its interacting environmental, economic, political, health and cultural dimensions.

Though broken down here into separate dimensions, taken together the special issue highlights the interactions between these dimensions and the importance of looking at topics comprehensively. Security in one dimension inevitably have a cascading effect on others that need to be approached holistically to find the most effective solutions. The insecurities of climate change, arguably the biggest transformative force in the Arctic, is just one example. The Arctic is warming at a rate of almost twice as much as the global average, making the effects of climate change in the circumpolar North far more intense and rapid than most of ecosystems on the globe. Insecurities that come with such rapid warming are found in all the dimensions that the authors of the special issue explore.

\section{The Copenhagen School and widened Arctic security studies}

The widened security perspective emerged in the immediate post-Cold War period by challenging the dominant IR approaches of Realism and Liberalism through formulating a discursive take on and by broadening the understanding of security (Buzan and Hansen 2009, 187-191). As part of this constructivist turn, the Copenhagen School developed as an amalgamation of diverse elements: Barry Buzan (1983) organized and expanded a range of phenomena relevant for security into distinct economic, environmental, societal, 
political, and military sectors. Ole Wæver $(1995)^{1}$ conceptualized security as the result of a specific type of speech acts (securitizations), and sectors became the name for 'second order observations' (Wæver 1999) of distinct 'dialects' of securitization (Wæver 1997, 356). In 1998, Buzan, Wæver and de Wilde tied these ideas together in their momentous book Security: A New Framework for Analysis. With this theoretical legacy in mind, the present issue is organized to reflect the varied sectoral security issues with particular focus on the communication defining whether something is constructed as being threatened within the Arctic. Five articles use Wæver's securitization approach to unpack five different cases of security within the circumpolar region. The final article, by Heather ExnerPirot and Robert Murray, uses the English School of security studies which Barry Buzan is also a part of. In this light, we find it appropriate to explain the most basic ideas of Wæver's theory here, while further nuances, possible points of critique and various ways of using the theoretical tools will be explained and demonstrated in the individual chapters.

According to Wæver, security is intersubjective and discursively constructed (Wæver 1995, 55) in a self-referential and contingent process constantly open for restructuration (Buzan et al. 1998, 204). A securitization act happens when a securitizing actor with a significant ethos declares a valued referent object to be existentially threatened (Buzan et al. 1998, 36). In the sectors relevant to the chapters in this issue - the military, the societal and the environmental - the referent objects are the sovereignty of the state, large-scale collective identities, humankind, and other species that may be externally threatened by e.g. other states, migration, and climate changes (Buzan et al. 1998, 22-23). Whether the securitization act is successful or remains a mere attempt depends on the reception by a relevant audience - often agenda setting politicians, bureaucrats, media, and academics - who accepts or rejects the securitization act, hence deciding if exceptional measures should be allowed to protect the threatened referent object (Buzan et al. 1998, 23-26). In this way, the audience is both decisive (Wæver 2003, 11) and passive as it is only if the audience explicitly denies the securitization act that it can be concluded that it was just an unsuccessful attempt (Buzan et al. 1998, 26). A successful securitization act may, on the other hand, involve suspension of civil and liberal rights that otherwise would have been respected if the referent object had remained on the lower discursive level of normal politics (Buzan et al. 1998, 23-24). The decision to label something a security problem does not, however, reflect whether the relevant object is threatened per se, instead it is a political, and usually elitist, decision taken with the purpose of legitimizing specific and often state-centered solutions (Wæver, 1995, 57; 65). The opposite of security is not, as one might think, insecurity, as insecurity is when a security issue is present when a means to avert the threat either does not exist or has not been implemented (Wæver, 1995, 56). Instead, the binary opposition to security is desecurity, which happens when a securitized issue is discursively removed from the sphere of security. Contrary to

\footnotetext{
${ }^{1}$ The early stages of the concept are explained in a 1989 working paper entitled Security, the Speech Act, Analysing the Politics of a Word which, however, does not mention the securitization concept by its name.
} 
securitization, the process of desecuritization follows democratic rules and procedures of transparency and accountability when it occurs within a system where normal procedures are democratic. It is, thus, found on the lower discursive level of normal politics (Wæver 1995, 56-57).

In the 1980's and early 1990's, the IR literature about the Arctic was largely descriptive (Jensen 2016, 4) with most of the few theoretically inspired contributions situated in the institutionalist camp with Oran R. Young $(1994,1999)$ as the most prominent name. After some delay, poststructuralism has, however, also got a hold of circumpolar IR studies with thanks to the informed authorships of i.a. Iver B. Neumann (1994), Geir Hønneland (1998) and Carina Keskitalo (2004) who have scrutinized the discursive region-building and identity formation in the Arctic. More recently, the securitization approach has also slowly become a still more popular analytical lens. It has i.a. been used to show how the Cold War as a macrosecuritization frame hierarchized multiple other security issues in the Canadian Arctic, enabling securitizing actors to portray threats within one sector as threatening to a referent object in another sector as well, resulting in a securitizing dilemma (Watson 2013); how Mikhail Gorbachev's famous Murmansk speech was an act of desecuritization paving the way for normal politics (Åtland 2008); how the Elektron incident (Åtland 2009) and Greenpeace's attempt to board Gazprom's Prirazlomnaya oil rig in the Pechora Sea (Palosaari and Tynkkynen 2015) were sought securitized by some Russian actors; how the effects of climate change prompted difference reactions by the Canadian Inuit and the Sámi in Norway (Greaves 2016); how the concept of security is omnipresent in the Norwegian High North discourse (Jensen 2013); how Greenland has managed to get a foreign policy more autonomous from Denmark by referring to a threatened national identity (Jacobsen 2015); how the Greenlandic uranium debate activates securitization talks in relation to both the political, environmental, and economic sector in what is basically a debate about what kind of country Greenland should strive to be (Kristensen and Rahbek-Clemmensen 2017); and finally how the number of securitization attempts and successful securitization acts in the Arctic correlates with the increased number of Arctic strategies and geopolitical demarcation (Albert 2015). It is in line with these inspiring contributions that the articles within this issue aim to take this scholarship further by showing how securitization can be used as a fruitful analytical tool to gain new perspectives on the complexities of Arctic international relations.

Marc Jacobsen and Jeppe Strandsbjerg's article 'Desecuritization as Displacement of Controversy: geopolitics, law and sovereign rights in the Arctic' demonstrates how the Ilulissat Declaration was a pre-emptive desecuritization act in reaction to the growing concern for military conflict in the wake of the Russian flag planting. It happened through agreeing that science and international law shall determine the delineation of the Arctic Ocean, but while it was successful in silencing securitization attempts this shift to other government techniques simultaneously generated new dilemmas and controversies: within international law there has been controversy over its ontological foun- 
dations and within science we have seen controversy over specific standards, hence challenging the notion of 'normal politics'. While minimizing the horizontal conflict potential between states, this development has simultaneously given way for vertical disputes between the signatory states on the one hand and the Indigenous peoples of the Arctic on the other.

Wilfrid Greaves and Daniel Pomerants investigate in their article "Soft Securitization': Unconventional Security Issues and the Arctic Council' if the Arctic Council has sought to discursively construct particular security issues via its declarations and other official outputs. Through a textual analysis of the publicly available documents, they examine the Council's use of security language to assess whether such rhetoric is mobilized to identify specific threat-referent relationships or in an 'adjectival' sense that does not construct particular issues as existentially threatening. They, moreover, reflect on the analytical usefulness of the securitization theory, and the dynamics of constructing unconventional and contested security threats in a multilateral intergovernmental forum.

Heather Exner-Pirot and Robert Murray use the theoretical approach of the English School in their article 'Regional Order in the Arctic: Negotiated Exceptionalism' to explain the current state of affairs in the Arctic which continues to be marked by cooperation and stability. The reason for this is that states with involvement in the region have worked to negotiate an order and balance of power predicated on norms such as cooperation and multilateralism. The establishment of an Arctic international society has seen great powers and smaller powers come together to form an order aimed at promoting norms and institutions not seen elsewhere in the world. An Arctic international society has, thus, been deliberately negotiated in a way that promotes cooperation between Arctic states. However, this order can be disrupted if Arctic international society does not take conscious steps to maintain a strong institutional framework that protects Arctic internationalism.

Victoria Herrmann explores the gap between Arctic societal security discourse and tangible climate change commitments to Arctic Indigenous peoples in UN climate negotiations in 'Arctic Indigenous Societal Security at COP21: The Divergence of Security Discourse and Instruments in Climate Negotiations'. The article argues that the space for and use of Arctic societal security discourses at COP21 are not matched with climate commitments. Thus, the resulting global policy initiatives to support adaptation and mitigation in the North do not adequately support the security of current cultural practices and heritage in the Arctic. Empowering native culture of the North as a reason for acting on climate, but not empowering its security through tangible financial, legal, or technical commitments creates a post-colonial inequality in power in cultural security discourses and commitments.

Rasmus K. Rasmussen and Henrik Merkelsen's article 'Post-colonial governance through securitization? A narratological analysis of a securitization controversy in contemporary Danish and Greenlandic uranium policy' combines the securitization approach with theory of risk and narratological methodology in their analysis of the DanishGreenlandic government debates about potential uranium exploitation. They conclude 
that the securitization controversy visible at the surface level of policy documents reflects an identity struggle at the deeper narrative level closely related to the understanding of national identity politics. These underlying stakes are brought to the fore when securitization is used as a governance technique.

Ulrik Pram Gad's article entitled 'What kind of nation state will Greenland be? Securitization theory as a strategy for analyzing identity politics' modifies the analytical strategy prescribed by Copenhagen School Securitization Theory to produce a nuanced picture of national identity politics, the tensions involved, and scenarios for the future. An analysis of the 2002 and 2016 debates on language supplements the received image of what constitutes Greenlandic identity, centered on language and iconic material cultural practices, with conspicuously modern elements like democracy and welfare. Advancing formally from 'home rule' to 'self-government' has shifted the debate towards material challenges - prompting a more prominent role for the English language, in turn pointing Greenland towards new alliances in Arctic geopolitics.

Ole Waver's afterword reflects on three aspects of this special issue: First, what kind of total picture emerges from the analyses, i.e. how does the special issue add up to an understanding of 'Arctic international relations' and 'Arctic security'. And what are the main implications hereof? Second, he points out how some of the theoretical observations and innovations made by the contributors deserve to be identified and evaluated for their potential general relevance beyond an Arctic setting. Third, he suggests how the Copenhagen School's third leg 'regional security complexes - in addition to securitization and sectors - could also play a role in this special issue and in other similar analyses of Arctic security developments.

It is the hope that all these articles will spur scholars from across the globe to consider and debate the complex and comprehensive security challenges and opportunities presented in the circumpolar north. Today more than ever before, the northernmost reaches of the world are integrated into the international system. Although the North has always been connected to the rest of the world through trade networks and migratory routes, globalization, and climate change have created unprecedented connectivity through communication systems, global markets, and environmental cooperation. Such linkages have made the northern environment and its peoples very much a part of, and influenced by, the international economic, political, and cultural security developments of today. So too have these connections brought important non-Arctic emerging powers like China, India, and South Korea into Arctic governance and investment decisions, shifting alliances and multilateral cooperation within and below the Arctic Circle on international affairs. With increasing economic, military, and environmental interest in the Arctic region, it is vital to understand both the challenges and opportunities of evolving insecurities to ensure that publics and politicians alike are provided with a balanced, comprehensive understanding of the region. As you embark on this special issue, we leave you with this: the significance of understanding circumpolar security dynamics is global in impact. As you consider each chapter and the securitization concepts therein, we encourage you to consider how the approach of the Copenhagen School can open up, or 
perhaps reorient, your own work to include widened security perspectives and issues whether in the Arctic or beyond, through trade networks, energy production, and climate change that stretch southwards.

\section{Acknowledgements}

We would like to thank our distinguished reviewers ${ }^{2}$ - Mathias Albert, Lill Rastad Bjørst, Lassi Heininen, Leif Christian Jensen, Kathrin Keil, Kristian Søby Kristensen, and Teemu Palosaari - who themselves have made insightful contributions to widening the security approach in the study of Arctic international relations. Thank you to participants and attendees at our 2017 ICASS IX panel Many Arctics, Many Securities: Circumpolar International Relations in a Widened Security Perspective who provided thoughtful comments on our presentation of one of the final drafts of this issue. Last but not least, we are thankful to our brilliant colleagues at Centre for Advanced Security Theory, Scott Polar Research Institute, and The Arctic Institute, who make the study of circumpolar security developments an always enjoyable and inspiring ride.

Bibliography

Albert, M. (2015). The polar regions in the system of world politics: social differentiation and securitization. Geographische Zeitschrift, vol. 103(4), pp. 217-230.

Buzan, B. (1983). People, States, and Fear: The National Security Problem in International Relations. Brighton: Wheatsheaf Books.

Buzan, B., Wæver, O. and Wilde, J. de. (1998). Security: A New Framework for Analysis. London: Lynne Rienner Publishers.

Buzan, B. and Hansen, L. (2009). The Evolution of International Security Studies. New York: Cambridge University Press.

Cohen, A., Szaszdi, L.F. and Dolbow, J. (2008). The New Cold War: Reviving the US Presence in the Arctic. The Heritage Foundation Backgrounder, 30. Available at: http://www.heritage.org/environment/report/the-new-cold-war-reviving-the-uspresence-the-arctic [Accessed 4 September 2017].

Gad, U., Schlæger, J. and Strandsbjerg, J. (eds.). (2011). Arktis: Suverænitet, Styring, Geopolitik. POLITIK, vol. 14(1). Jurist- og Økonomforbundets Forlag. Available

\footnotetext{
${ }^{2}$ All reviews have been 'double blinded'. Though the names of all involved are hereby made public (after previous consent) it is still, however, secret who the reviewer for each individual article is. We have chosen to make reviewers' names public in order to show our sincere gratitude and to guide readers' attention towards their authorships in case one finds the widened security approach fruitful in the study of Arctic international relations.
} 
at: https://tidsskrift.dk/index.php/politik/issue/view/3934 [Accessed 5 August 2017].

Greaves, W. (2016). Arctic (in)security and Indigenous peoples: Comparing Inuit in Canada and Sámi in Norway. Security Dialogue, vol. 47(6), pp. 461-480.

Herrmann, V. (2015). The Cold War of global warming: recycled visual narratives from the top of the world. Polar Geography, vol. 38(4), pp. 289-305.

Hough, P. (2013). International Politics of the Arctic: Coming in from the Cold. Abingdon: Routledge.

Hønneland, G. (1998). Identity formation in the Barents Euro-Arctic Region. Cooperation \& Conflict, vol. 33, pp. 277-297.

Jacobsen, M. (2015). The Power of Collective Identity Narration: Greenland's Way to a more autonomous Foreign Policy. In: L. Heininen, H. Exner-Pirot and J. Plouffe (eds.). Arctic Yearbook 2015: Arctic Governance and Governing. Akureyri, Iceland: Northern Research Forum, pp. 102-118.

Jensen, L.C. (2013). Seduced and Surrounded by Security: A Post-Structuralist Take on Norwegian High North Securitizing Discourses. Cooperation and Conflict, vol. 48(1), pp. 80-99.

Jensen, L.C. (2016). International Relations in the Arctic: Norway and the Struggle for Power in the New North. London, New York: I. B. Tauris.

Johnson, K. and de Luce, D. (2016). Amid a Global Boom in Icebreaker Construction, the United States Risks Getting Frozen Out of the Melting Arctic. Foreign Policy. 24 May.

Keskitalo, E.C.H. (2004). Negotiating the Arctic, the construction of an international region. London: Routledge.

Kristensen, K.S. and Rahbek-Clemmensen, J. (2017) (forthcoming). Greenlandic Sovereignty in Practice: Uranium, Independence, and Foreign Relations in Greenland between Three Logics of Security. In: K.S. Kristensen and J. Rahbek-Clemmensen (eds.). Greenland and the International Politics of a Changing Arctic: Postcolonial Paradiplomacy between High and Low Politics. Taylor Francis Group, Routledge.

Neumann, I.B. (1994). A region-building approach to Northern Europe. Review of International Studies, vol. 20(1), pp. 53-74.

Palosaari, T. and Tynkkynen, N. (2015). Arctic securitization and climate change. In: L.C. Jensen and G. Hønneland (eds.). Handbook of the Politics of the Arctic. Cheltenham, UK: Edward Elgar, pp. 87-104.

Scarborough, R. (2017). Ice-cold War: Russian Icebreakers Outnumber U.S. Vessels in Vital Arctic. The Washington Times. 19 February.

Watson, S. (2013). Macrosecuritization and the Securitization Dilemma in the Canadian Arctic. Critical Studies of Security, vol. 1(3) pp. 265-279.

Wæver, O. (1995). Securitization and Desecurization. In: R. D. Lipschutz (ed.). On Security. New York: Columbia University Press, pp. 46-86. 
Wæver, O. (1997). Concepts of Security. Copenhagen: Department of Political Science, University of Copenhagen, $\mathrm{PhD}$ Dissertation.

Wæver, O. (1999). Securitizing Sectors? Reply to Eriksson. Cooperation and Conflict, vol. 34(3), pp. 334-340.

Wæver, O. (2003). Securitization: Taking Stock of a Research Programme. Paper presented at the PIPES, University of Chicago, March.

Young, O.R. (1994). International Governance: Protecting the Environment in a Stateless Society. Ithaca, NY: Cornell University Press.

Young, O.R. (1999). Arctic Politics: Conflict and Cooperation in the Circumpolar North. Hanover: Dartmouth College Press.

Åtland, K. (2008). Mikhail Gorbachev, the Murmansk Initiative, and the Desecuritization of Interstate Relations in the Arctic. Cooperation and Conflict, vol. 43(3), pp. 289311.

Åtland, K. (2009). When Security Speech Acts Misfire: Russia and the 'Elektron' Incident. Security Dialogue, vol. 40(3), pp. 333-353. 